\title{
Analisis Semiotika Iklan Aqua Kids 2020
}

\author{
Bryan Marsheilo" ${ }^{1}$ H.H. Daniel Tamburian ${ }^{2 *}$ \\ ${ }^{1}$ Fakultas Ilmu Komunikasi, Universitas Tarumanagara, Jakarta \\ Email: bryan_915170131@stu.untar.ac.id \\ ${ }^{2}$ Fakultas Ilmu Komunikasi, Universitas Tarumanagara, Jakarta* \\ Email:danielt@fikom.untar.ac.id
}

Masuk tanggal : 15-12-2021, revisi tanggal : 06-01-2022, diterima untuk diterbitkan tanggal : 16-01-2022

\begin{abstract}
Advertising is a complex form of communication that is useful for influencing the thoughts, feelings and actions of consumers for the benefit of the advertiser. Advertising is also a form of communication that has a complex message because it has signs in it. Includes Aqua ad. Aqua created a new advertisement with a target market for children. This is interesting to research because drinking water is a product that can be consumed by all ages, but Aqua decided to create a new segment in its products, therefore its new advertisement must have many signs that it wants to convey to potential consumers, thus it requires semiotic techniques. . Semiotics is the study of signs and anything related to signs. This research is a qualitative research using the semiotic analysis method of Roland Barthes, collecting data by observing and observing the Aqua Kids advertisement. The researcher takes the scenes in the advertisement and identifies the signs and messages in each scene, with connotative and denotative. The results showed that children had difficulty concentrating in online learning activities, but when Aqua kids were there, the problem disappeared.
\end{abstract}

Keywords: aqua, Roland Barthes, semiotics of advertising

\begin{abstract}
Abstrak
Periklanan adalah bentuk komunikasi kompleks yang berguna untuk memengaruhi pikiran, perasaan dan tindakan konsumen demi kepentingan pengiklan. Iklan juga merupakan bentuk komunikasi yang memiliki pesan yang kompleks karena memiliki tanda-tanda di dalamnya. Termasuk iklan Aqua. Aqua membuat sebuah iklan baru dengan target market anak-anak. Hal ini menjadi menarik untuk diteliti karena air minum merupakan produk yang dapat dikonsumsi oleh segala jenis usia, namun Aqua memutuskan untuk membuat segmen baru dalam produknya, oleh karena itu iklan barunya pasti memiliki banyak tanda yang ingin disampaikan kepada calon konsumen, dengan demikian dibutuhkan teknik semiotika. Semiotika merupakan studi yang mempelajari tentang tanda dan apapun yang berhubungan dengan tanda. Penelitian ini merupakan penelitian kualitatif dengan metode analisis semiotika Roland Barthes, pengumpulan data dengan cara observasi dan mengamati iklan Aqua Kids. Peneliti mengambil scene-scene dalam iklan tersebut dan mengidentifikasi tanda dan pesan dalam setiap scene, dengan konotatif dan denotatif. Hasil penelitian menunjukkan, anak sulit berkonsentrasi dalam kegiatan belajar secara online, namun ketika ada Aqua kids, masalah tersebut hilang.
\end{abstract}

Kata Kunci: aqua, Roland Barthes, semiotika iklan

\section{Pendahuluan}

Periklanan adalah suatu bentuk komunikasi kompleks yang diciptakan guna mendapatkan tujuan tertentu, serta menggunakan strategi yang telah dirundingkan untuk mempengaruhi pikiran, perasaan, dan tindakan konsumen. Selain termasuk 
dalam komunikasi massa, iklan juga termasuk dalam komunikasi pemasaran, karena banyak mengacu kepada seluruh bentuk teknik komunikasi untuk memasarkan produk dan mendapat konsumen serta menyampaikan pesan (Sari, 2015).

Semiotika adalah studi tentang tanda dan apapun yang berhubungan denganya, bisa cara fungsinya, hubungan dengan tanda yang lain, pengirim, atau juga penerima. Tanda adalah hal yang mewakili sebuah objek, atau keadaan, perasaan, dan sebagainya, yang berada diluar tanda itu sendiri, artinya dibutuhkan untuk mengerti tentang makna dari tanda ini (Mabrukah, 2018 : 12).

Tahun 2020 merupakan tahun yang mengejutkan karena pandemi COVID-19 yang melanda Indonesian, dan negara-negara lain, telah membuat perubahan siginifikan kedalam kehidupan manusia. Budaya baru pun muncul, yakni orang mulai bekerja dan belajar secara mandiri di rumah.

Budaya ini tidak dibiarkan begitu saja oleh perusahaan pemilik produk. Mereka memanfaatkan keadaan yang baru ini untuk memasarkan produk-produk mereka, dengan mengangkat masalah yang nyata dalam iklan. Dengan demikan khalayak mendapat kesamaan pengertian segingga dapat mengerti iklan lebih mudah. Namun tidak hanya itu, iklan juga mengonstruksi realitas yang baru, menaruh pemikiran ke dalam iklan demi kepentingan pengiklan (Haryono and Putra, 2017 )

Pada penelitian ini penulis lebih berfokus kepada aspek pesan yang dikonstruksi dan juga tanda dalam sebuah iklan, dengan media massa televisi. Iklan yang ingin diteliti adalah iklan air mineral dengan merk Aqua. Aqua adalah salah satu perusahaan yang memproduksi air mineral di dalam kemasan, dan merupakan merek yang besar dibanding pesaing-pesaingnya. Aqua pertama kali diproduksi di Indonesia sejak tahun 1973 oleh Aqua Golden Mississipi (NUSA, 2011 : 69).

Topik ini menjadi menarik untuk diteliti karena, secara jika dibandingkan produk antara Aqua yang pada umumnya dengan Aqua kids ini hanya memiliki perbedaan pada kemasan produk. Membangun segmentasi baru secara khusus di kalangan anak-anak memanfaatkan kondisi pandemi ini. Selain itu berdasarkan website top brand award, Aqua merupakan Top Brand nomor satu pada kategori air minum dalam kemasan selama 5 tahun berurut-urut (https://www.topbrandaward.com/)

Dalam iklan barunya Aqua dengan durasi 30 detik, memerlihatkan seorang anak yang kesulitan belajar secara online dikarenakan gangguan yang ada di sekitar rumah tersebut. Iklan ini juga menunjukkan juga seorang ibu yang sudah melakukan berbagai macam cara namun anak tersebut tidak kunjung konsen dalam mengerjakan tugas. Iklan ini sangat menarik karena sangat bisa dikaitkan dengan kehidupan sekarang yang ditengah kondisi pandemi. Iklan ini di siarkan melalui televisi dan juga sosial media Youtube

Pada penelitan ini peneliti ingin mengetahui tentang makna dan pesan yang terkandung dalam iklan Aqua kids, dan juga bagaimana sistem tanda secara denotasi dan konotasi dalam iklan Aqua Kids.

\section{Metode Penelitian}

Dalam penelitian ini, penulis menggunakan pendekatan kualitatif, pendekatan ini digunakan untuk memaksimalkan penelitian secara mendalam megenai semiotika iklan Aqua kids. Penelitian kualitataif adalah segala jenis penelitan yang tidak menggunakan prosedur statistik. Metode kualitatif lebih menekan kepada 
pengamatan suatu fenomena dan meneliti tentang substansi makna dari fenomena tersebut (Basri, 2014 : 832).

Penelitian menggunakan analisis iklan dengan model analisis semiotika Roland Barthes. Semiotika disebut sebagai ilmu tentang tanda. Semiotik merupakan studi mengenai arti dan analisis dari kejadian atau peristiwa yang menimbulkan atau membuat arti. Analisis semiotika Roland Barthes memiliki dua signifikasi tahap yaitu tahap pertama merupakan hubungan antara Signifier dan Signified yang disebut denotasi, yang berarti makna yang sebenarnya dari tanda. sedangkan Signifikasi kedua adalah konotasi yang berarti makna subjektif kemudian berhubungan dengan isi dan tanda yang bekerja melalui mitos (Triandjojo, 2008)

Peneliti mengumpulkan data melalui observasi dan pengamatan dengan menonton iklan Aqua Kids 2020. Melalui pengamatan, peneliti mengidentifikasi sejumlah scene yang berisi simbol atau tanda pada iklan Aqua Kids 2020 (Hasanah, 2017). Pemaknaan tersebut akan diinterpretasikan penulis melalui analisis semiotika. Selain itu penelitian ini juga menggunakan sumber-sumber lain antara lain buku, jurnal, juga reverensi lain yang terkait dengan penelitian iklan air minum dalam kemasan Aqua versi "Aqua Kids".

Teknik analisis yang digunakan bertujuan untuk mengelompokan, memberi tanda, dan mengkategorikan tanda sehingga mendapatkan temuan yang terfokus kepada masalah yang ingin dijawab

1. Tahap reduksi data

Reduksi data adalah kegiatan merangkum, memfokuskan hal-hal penting, sehingga dapat memberikan gambaran jelas dan mempermudah pengumpulan data

2. Penyajian data

Penyajian data adalah upaya untuk mengumpulkan data sehingga ada kemungkinan untuk penarikan kesimpulan dan pengambil tindakan

3. Penarikan kesimpulan

Merupakan hasil yang menjawab fokus penelitian berdasarkan hasil analisis data, dan disajikan dalam bentuk deskriptif objek penelitian dengan pedoman pada kajian penelitian.

\section{Hasil Temuan dan Diskusi} Aqua kids:

Penulis akan membagikan hasil temuan pada sejumlah scene dalam iklan

0:01 - 0:04

Kakak : "Si kakak, susah banget konsentrasi kalau lagi belajar "

Adik : "Yey"

Gambar 1. Scene 1 Detik ke-2

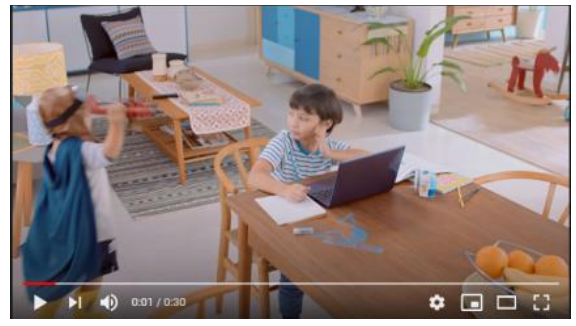

Sumber: Youtube 
Denotatif: Pada visual 1 memperlihatkan keadaan rumah yang sangat bersih, dan penataan letak barang yang rapi di sekitar ruangan, namun di meja tempat kakak belajar ada tumpukan penggaris dan pensil yang tidak tertata rapi, dan kakak sedang melihat adik bermain dengan pesawat kecilnya sambil berlari, dan laptop yang diabaikan oleh kakak. Visual secara keseluruhan didominasi oleh warna Coklat.

Konotatif: Menunjukkan keadaan rumah yang sedang berada didalam kondisi pandemi mengikuti keadaan yang sekarang benar-benar terjadi di masyarakat. Menunjukkan juga jika anak belajar dirumah dapat terganggu dan sulit untuk berkonsentrasi, meskipun sedang ditengah pembelajaran, karena laptop ada di hadapannya. Secara keseluruhan juga menunjukkan kondisi keluarga yang berkecukupan karena banyak furnitur-furnitur, serta terlihat rumahnya terlihat cukup luas sehingga tidak dapat tertangkap kamera secara keseluruhan. Dari segi warna, coklat menunjukkan sebuah kehangatan, membumi dan keamanan.

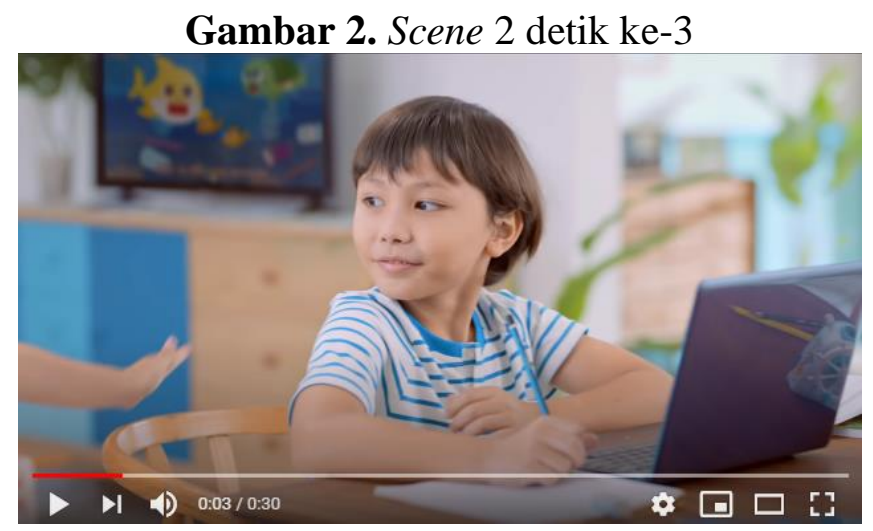

Sumber: Youtube

Denotatif: Menunjukkan kakak yang sedang tersenyum saat melihat adik bermain dengan pesawat kecilnya, dengan masih mengabaikan laptop. Televisi yang menunjukkan animasi kartun untuk anak kecil mirip dengan yang ada di lagu "Baby Shark". Warna lebih di dominasi oleh warna biru, coklat, dan putih secara seimbang.

Konotatif: Kakak yang menoleh kepada adik, menunjukkan sulitnya si kakak untuk berkonsentrasi, dan juga mengabaikan laptop dapat berarti juga tidak memperhatikan pembelajaran yang diberikan oleh guru, saat sekolah daring. Animasi yang berada di televisi menunjukkan kalau ini merupakan iklan yang ditujukan khusus untuk anakanak, karena lagu "Baby shark" cukup terkenal dan mendunia, sampai December 2020, lagu tersebut sudah di tonton sebanyak 7.4 juta kali. Warna biru memiliki makna kesegaran, dan dingin, sedangkan putih memiliki makna kebersihan dan kemurnian.

0:05 - 0:07

"Aku coba berbagai cara, ga ada yang berhasil"

Visual 5: Kakak: "mm.." sambil menggelengkan kepala 
Gambar 3. Scene 4 Detik ke-5

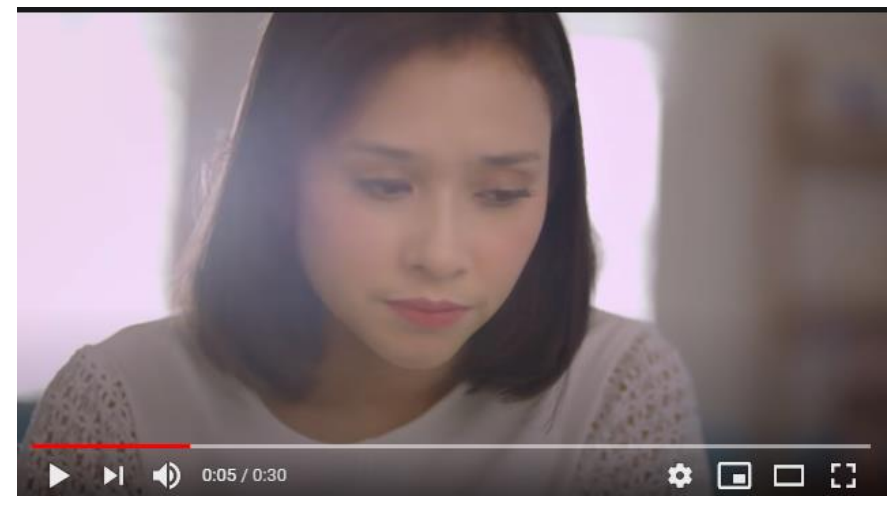

Sumber: Youtube

Denotatif: Menunjukkan raut muka ibu yang sedih, bingung dan tidak tahu harus bagaimana lagi, visual yang menunjukkan bagian belakang ibu bersinar dan membuat raut muka ibu semakin muram.

Konotatif: Wajah ibu yang terlihat sedih menggambarkan perasaan seorang ibu yang melihat anaknya tidak dapat belajar dengan konsentrasi, hal ini didukung dengan cara pengambilan gambar yang memanfaatkan cahaya dari belakang ibu, sehingga menimbulkan efek wajah ibu semakin gelap yang dapat berarti suasana hatinya yang sedang gelap dan sedih.

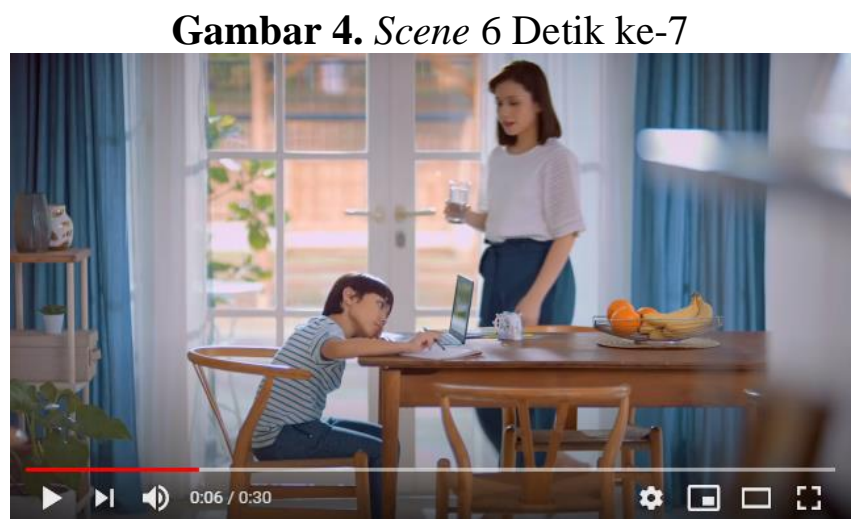

Sumber: Youtube

Denotatif: Ibu membawakan segelas air putih untuk kakak. Kakak sedang membaringkan kepalanya sambil melihat laptop, atau belajar dan menggoyangkan pensilnya. Suasana ruangan terlihat lebih gelap dibandingkan sebelumnya.

Konotatif: Kakak yang sedang melihat kearah laptop namun sambil membaringkan kepalanya dapat dikaitkan dengan kakak sebetulnya tidak memiliki niatan untuk belajar, atau kegiatan dilakukan dengan terpaksa, sehingga tidak ada semangat dan membaringkan kepalanya. Ibu membawakan segelas air putih yang menandakan rasa perhatian ibu kepada si kakak, dan juga merupakan upaya ibu untuk membuat kakak semangat belajar. Pencahayaan yang kurang dapat diartikan sebagai suasana yang tidak baik. 
Gambar 5. Scene 8 Detik ke-7

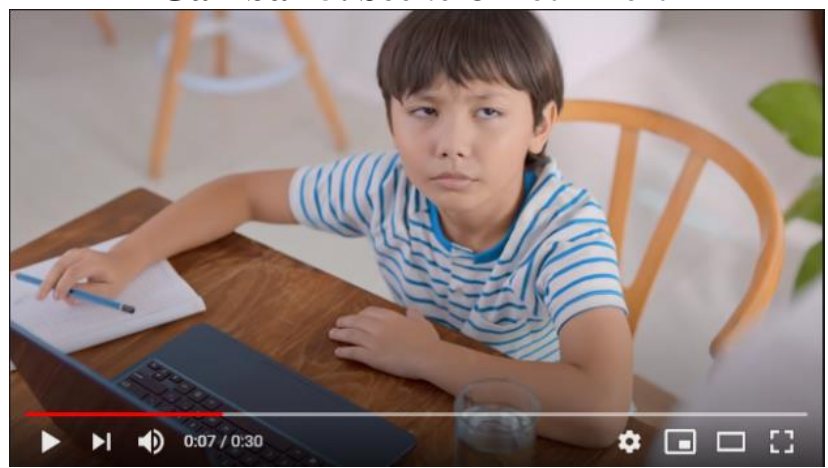

Sumber: Youtube

Denotatif: Kakak melihat gelas dan menggelengkan kepala kepada ibunya, dan juga menampilkan muka yang tidak senang dengan apa yang dibawa oleh ibunya.

Konotatif: Kakak melihat kearah gelas, menandakan dia tahu dan mengenal apa yang dibawa oleh ibunya, namun karena tidak menarik bagi kakak maka ia menggelengkan kepala sebagai tanda dia tidak menginginkan segelas air mineral tersebut, hal ini didukung dengan, kakak mengucapkan "mm.." sambil menggelengkan kepalanya. Kakak juga memainkan alat tulisnya yang dapat berati kakak tidak fokus dalam belajarnya.

$0: 20-0: 24$

"Ayo ajak si kecil, cukupi kebutuhan minum untuk bantu meningkatkan perfoma kognitifnya."

Suara kakak "Saya Bu!"

Gambar 6. Scene 15 Detik ke-21

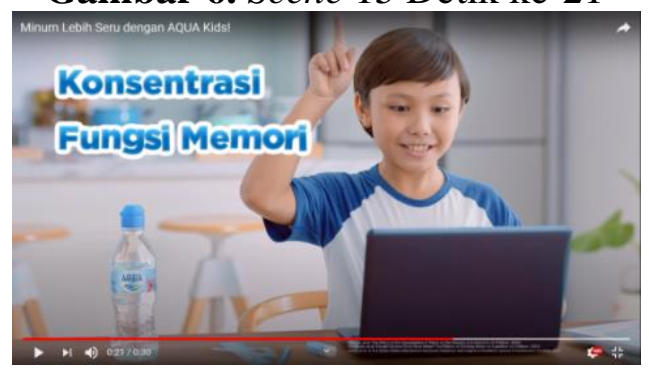

Sumber: Youtube

Denotatif: Kakak yang fokus terhadap laptop, disertai dengan keberadaan Aqua kids disebelah kirinya, dan juga menunjukkan kakak yang sedang mengangkat tangan kepada laptop. Disertai dengan teks: konsentrasi, fungsi memori.

Konotatif: Memberi pengertian kalau kakak memperhatikan dan mengingat apa yang telah diajarkan gurunya. Mengangkat tangan biasa dapat dihubungkan kalau kakak ingin menjawab pertanyaan yang diberikan oleh gurunya, hal ini didukung dengan kakak yang berkata "saya bu". 


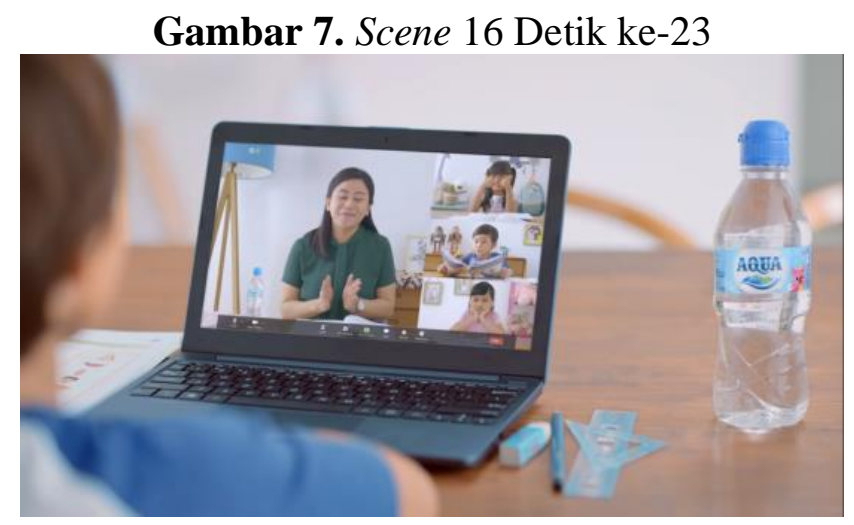

Sumber: Youtube

Denotatif: Memperlihatkan apa yang ada dihadapan kakak, atau yang ada di dalam laptop tersebut, tampak guru dan teman-temannya. Guru yang bertepuk tangan disertai dengan Aqua kids disebelah guru, teman yang mengangkat jempol, teman yang sedang membaca buku, dan juga teman yang menopangkan dagunya.

Konotatif: Memperlihatkan guru yang senang dengan kakak yang aktif saat ditanya oleh guru dengan bertepuk tangan, juga ingin menunjukkan kalau Aqua kids juga baik untuk dikonsumsi meskipun sudah bukan umur anak-anak. Teman-teman kakak yang ditunjukkan memiliki berbagai respon terhadap jawaban kakak kepada guru, menunjukkan keadaan disekolah yang sebenarnya, perbedaan sikap anak-anak. Ada yang malas, yang rajin, bahkan juga ada yang sangat suportif terhadap teman kelasnya.

\section{Simpulan}

Berdasarkan hasil penelitian, iklan Aqua Kids memiliki banyak aspek yang menarik perhatian dari penonton di Indonesia. Secara denotasi menggunakan permasalahan yang benar-benar terjadi di kalangan pelajar.

Selain itu, tanda secara konotasi dapat dilihat secara lebih jelas melalui ekspresi wajah yang dikeluarkan oleh ibu dan juga kakak dalam iklan tersebut, sulitnya anak dalam konsentrasi dapat terganggu dengan apa saja, bahkan aquarium yang ikannya hanya satu bisa jadi ganggunan yang besar bagi si anak untuk belajar.

Gambaran yang paling mencolok adalah saat ibu kebingungan, visual wajah ibu yang menunjukkan sudah tidak tahu harus bagaimana lagi untuk menghadapi anaknya agar dapat konsentrasi dalam belajar, dan juga visual warna putih dari belakang sehingga ibu terlihat lebih gelap yang cenderung dapat diartikan kesedihan atau kematiaan.(Monica and Luzar, 2011)

Dari segi visual yang kebanyakan didominasi oleh warna biru, putih, coklat, dan hijau. Penyampaian pesan secara implisit melalui tanda-tanda menggunakan warna-warna yang yang spesifik membantu penonton juga memikirkan tentang kemurnian (putih), kesegaran (biru), ramah terhadap alam dan ketenangan (coklat dan hijau). Disisi lain, menarik juga ketika Aqua memberikan fakta tentang kebutuhan minum anak-anak, Aqua menyertakan sumber-sumber jurnal yang diambil, meskipun tulisannya kecil, dapat diartikan kalau Aqua tidak mengada-ngada dalam menyatakan suatu gagasan, dan juga sangat berperan aktif dalam menggunakan warna dengan baik untuk merepresentasikan merek dan produknya. 


\section{Ucapan Terima Kasih}

Peneliti ingin mengucapkan terima kasih kepada Fakultas Ilmu Komunikasi Universitas Tarumanagara, narasumber, serta semua pihak yang turut membantu peneliti sehingga penelitian ini dapat diselesaikan.

\section{Daftar Pustaka}

Basri, Hasan. (2014). "Using Qualitative Research in Accounting and Management Studies: Not a New Agenda." Journal of US-China Public Administration 11(10):831-38. doi: 10.17265/1548-6591/2014.10.003.

Haryono, Sinta Rizki, and Dedi Kurnia Syah Putra. (2017). "Identitas Budaya Indonesia: Analisis Semiotika Roland Barthes Dalam Iklan Aqua Versi 'Temukan Indonesiamu."' Acta Diurna 13(2):67-88.

Hasanah, Hasyim. (2017). "TEKNIK-TEKNIK OBSERVASI (Sebuah Alternatif Metode Pengumpulan Data Kualitatif Ilmu-Ilmu Sosial)." At-Taqaddum 8(1):21. doi: 10.21580/at.v8i1.1163.

Mabrukah, Risna Meidina. (2018). "ANALISIS SEMIOTIK MAKNA BERBAGI DALAM IKLAN AQUA VERSI 'SAYA INDONESIA' DI BILLBOARD SKRIPSI.” Director 15(29):7577-88.

Monica, Monica, and Laura Christina Luzar. (2011). "Efek Warna Dalam Dunia Desain Dan Periklanan." Humaniora 2(2):1084. doi: 10.21512/humaniora.v2i2.3158.

NUSA, OKTO DELFISIANUS TUNGGA. (2011). "ANALISIS SEMIOTIKA MAKNA PESAN IKLAN AIR MINUM DALAM KEMASAN AQUA VERSI 'SUMBER AIR SU DEKAT' DI MEDIA TELEVISI Oleh."

Sari, Wulan Purnama. (2015). "Konflik Budaya Dalam Konstruksi Kecantikan Wanita Indonesia (Analisis Semiotika Dan Marxist Iklan Pond's White Beauty Versi Gita Gutawa).” Jurnal Komunikasi 7(2):198-206.

Triandjojo, Indriani. (2008). "Semiotika Iklan Mobil Di Media Cetak Indonesia." 43-45. 